\title{
Carbonate Enrichment in Volcanic Debris and Its Relationship with Carbonate Dissolution Signatures of Springs in the Sabga-Bamessing, North West, Cameroon
}

\author{
Raymond Beri Verla ${ }^{1,2^{*}}$, Germain M. M. Mboudou ${ }^{1}$, Olivier Njoh', \\ Gilles Nyuyki Ngoran ${ }^{2,3}$, Aloysius Ngambu Afahnwie ${ }^{1}$ \\ ${ }^{1}$ Department of Geology, Faculty of science, University of Buea, Buea, Cameroon \\ ${ }^{2}$ Explorers 33 Consultants, Yaounde, Cameroon \\ ${ }^{3}$ Ministry of Mines, Yaounde, Cameroon \\ Email: verla6@yahoo.com
}

Received October 25, 2013; revised November 27, 2013; accepted December 13, 2013

Copyright (c) 2014 Raymond Beri Verla et al. This is an open access article distributed under the Creative Commons Attribution License, which permits unrestricted use, distribution, and reproduction in any medium, provided the original work is properly cited. In accordance of the Creative Commons Attribution License all Copyrights (C) 2014 are reserved for SCIRP and the owner of the intellectual property Raymond Beri Verla et al. All Copyright (C 2014 are guarded by law and by SCIRP as a guardian.

\begin{abstract}
Sabga-Bamessing is a part of the Bamenda Mountains, an extinct volcanic center of the West Cameroon Highlands along the Cameroon Volcanic Line (CVL). The pristine volcanic rocks of the Sabga area are alkali mafic to felsic (basanites, phonolites, trachytes and rhyolites). Some weathered sections of a heterolithologic debris flow with a suppositious primary chemistry of the original volcanic rocks prior to weathering have shown significant calcium carbonate enrichment. $\mathrm{CaO}$ and $\mathrm{LOI}$ values of up $61.31 \%$ and $41.72 \%$ respectively show corresponding enrichment of 16.54 and 10.88 , when compared with average fresh volcanic rocks. $\mathrm{Na}^{+}$normalized molar ratios computed from the chemistry of springs and rivers show carbonate dissolution signature which is contrary to silicate dissolution expected in acid volcanic rocks. Saturation indices (SI) calculated with PHREEQC reveal that brackish to saline springs are supersaturated with Calcite $\left(\mathrm{CaCO}_{3}\right)$, Aragonite $\left(\mathrm{CaCO}_{3}\right)$, Dolomite $\left(\mathrm{CaMg} \mathrm{CO}_{3}\right)_{2}$ and Hydroxyl apatite $\left(\mathrm{Ca}_{5}\left(\mathrm{PO}_{4}\right)_{3} \mathrm{OH}\right)$. Recharging contributions to spring water chemistry deviate from those produced by rock weathering, precipitation and evaporation/crystallization. An enrichment process is therefore predicted as a recharging contributor to water chemistry.
\end{abstract}

\section{KEYWORDS}

Cameroon Volcanic Line (CVL); Carbonate Enrichment; Carbonate Dissolution; Weathering

\section{Introduction}

The Cameroon Volcanic Line (CVL) is one of the major geological lineaments of the African plate and continent [1]. This $\mathrm{N} 30^{\circ} \mathrm{E}$ magmato-tectonic megastructure of Central Africa is a paradigm of active hot lines on Earth made up of continental and oceanic sectors; a unique feature in Africa and even in the world [2].

The Sabga-Bamessing area is a small locality on the west Cameroon highlands an extinct volcanic center of the CVL.

Numerous researchers have worked on the CVL and most attention is directed towards the genesis, petrogene-

${ }^{*}$ Corresponding author. sis and petrology, geochronology, and emplacement mechanisms of the volcanic rocks [2-7] and other references therein].

The Sabga-Bamessing area conforms to the general geology of the CVL but has certain peculiarities. Explosive volcanic activity evident by the presence of extensive ignimbrite sheets characterizes the area [8]. Field evidence has shown the brackish to saline nature of water draining certain sections of Sabga. The geochemical aspects of these fluids have not been fully studied but ample evidence shows that the fluids do not reflect the chemistry of the volcanic rocks. There is an evidence that $\mathrm{CaO}$ and Carbonate enrichment has occurred across the profile of a thick and extensive debris flow. The water 
chemistry of some springs has evolved; bearing a Carbonate dissolution signature. This paper presents new data showing the peculiarities in ground and surface water of Sabga due to enrichment and its non conformance to the chemistry of acid volcanic rocks which constitute the main lithology in the area.

\section{Geographical and Geological Context of the Sabga-Bamessing Area}

The Sabga area is located in the Central African Region in North West Cameroon. The area lies between latitude $6^{\circ} 00^{\prime} \mathrm{N}-6^{\circ} 2^{\prime} \mathrm{N}$ and longitude $10^{\circ} 20^{\prime} \mathrm{E}-10^{\circ} 22^{\prime} \mathrm{E}$.

The North West Region of Cameroon falls within the Equatorial climatic domain and precisely influenced by the Cameroon mountain type climate with two seasons; a rainy season from April to October and a dry season from November to March. Annual precipitation and temperature are about 1778 - $2286 \mathrm{~mm}$ and $20.5-22.3^{\circ} \mathrm{C}$ respectively. The vegetation of the study area is generally made of Terminalia trees and shrub savanna derived from moist evergreen forest [9]. The occurrence of bush fires and other anthropogenic activities have modified the vegetation. The study area equally has a guinea savanna type of vegetation with a mixture of stunted shrubs and grassy undergrowth and has been beneficial for cattle rearing for several decades. The Bamenda country-side also presents a vegetation of raffia palm bush limited to valleys and depressions [10]. Geologically, the Sabga area (Figure 1) is part of the Bamenda Mountains [11]. It is an extinct volcanic center of the West Cameroon Highlands. This center constitutes a very important part of the continental sector of the Cameroon Volcanic Line and lies mid-way between Bambouto in the south west and the Oku massif in the north east.

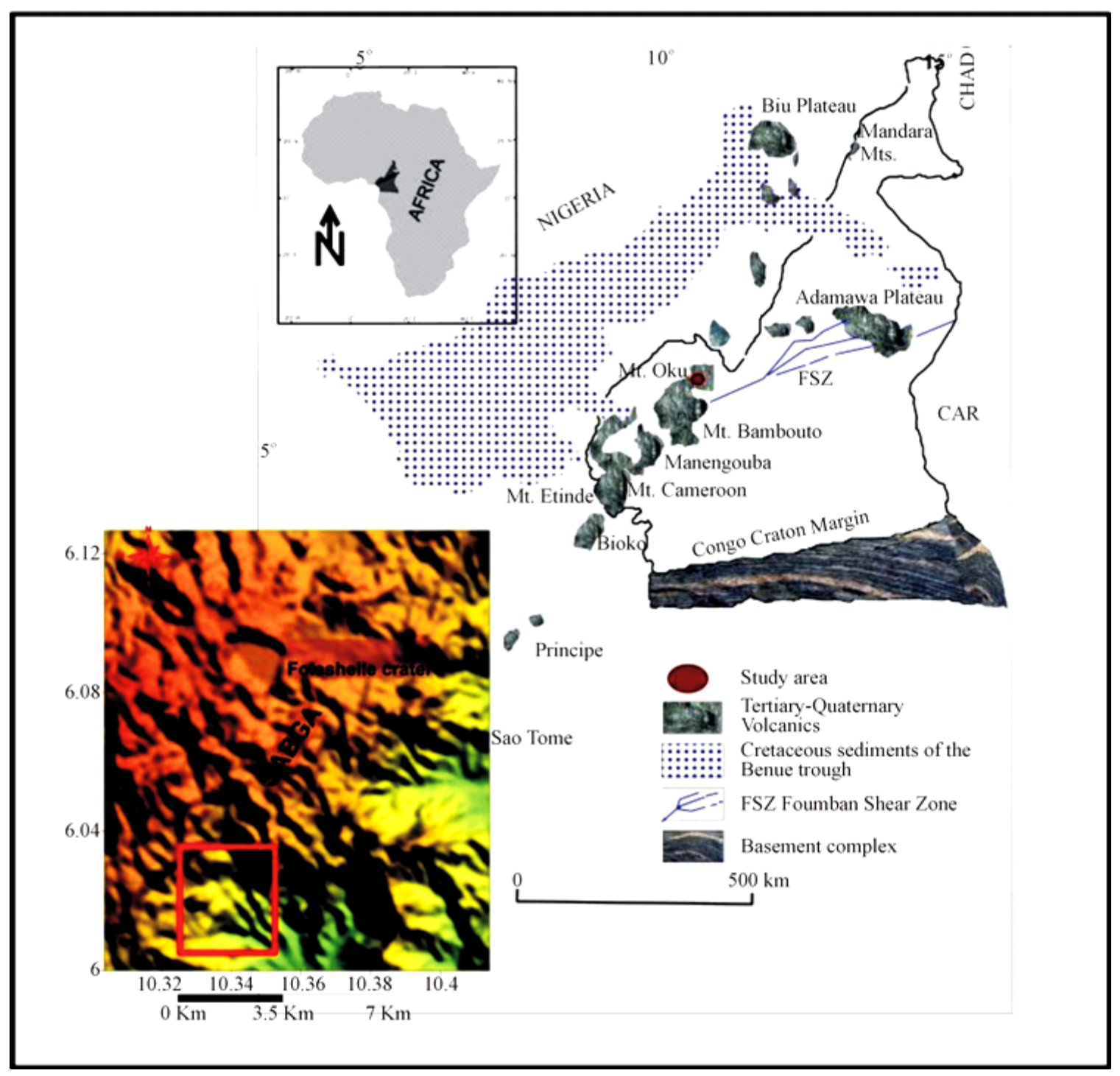

Figure 1. Location of the study area within the CVL; the study area is shown on the satellite image as a rectangle. 
The Sabga area lies just a few miles (about 15 miles) SE of Big Babanki, one of the stratovolcanoes on the Oku massif. The volcanic rocks range from mafic to felsic and include basalts, Mugearites, basanites, trachytes, rhyolites and benmoreites [11-13]. The absolute ages determined for the mafic volcanic rocks range from 10 to $22 \mathrm{Ma}$ from earlier studies; 12 to $27 \mathrm{Ma}$ following recent geochronogical data [11]. The ages determined for the felsic volcanic rocks range from 18.7 - 24.2 Ma for the oldest rocks and 12.7 - 13.2 Ma for the youngest ones. Geochemical studies had previously been done on nearby volcanic centers (Oku and Ndu) and similar geochronologic, petrogenetic and petrological conclusions had been drawn $[14,15]$. The volcanic rocks are emplaced on a granitic basement of Pan African age with extensive outcrops in the Bamessing, and Ndop plains. Field evidence reveals abundant muscovite in the mode of these granites.

\section{Sampling and Analytical Procedures}

Five representative samples from 33 fresh volcanic samples were selected for analysis. Five samples collected from the top and bottom of a weathered volcanic debris flow were equally selected. The samples were oven-dried at $105^{\circ} \mathrm{C}$. Each sample was disaggregated. The resulting chips were put in a porcelain cup together with porcelain balls, cocked tightly and milled for about 30 minutes. The resultant powder measuring about $100 \mu$ or more was put into clean porcelain mortar and using the physical energy, pulverized with a porcelain pestle to finer sizes. A clean $50 \mu$ sieve was used to sieve the pulp obtaining a $<50 \mu$ powder. Glass beads and pressed powder discs were made from the powder for major oxide and trace element analyses respectively.

A Pioneer S4 Brucker XRF apparatus was used to analyze for major and trace elements in ten samples at MIPROMALO (Mission de Promotion des Matériaux Locaux), Yaounde, Cameroon. Loss on ignition (LOI) was determined by weight difference after ignition at $1000^{\circ} \mathrm{C}$.

Twelve water samples (10 springs and 2 river samples) were collected using the conventional methods given in FOREGS geochemical manual [16]; water samples were collected with a syringe which had been rinsed twice with the water sample and put in $500 \mathrm{ml}$ ethylene bottle passing through a filter, followed by the addition of 1.0 $\mathrm{ml}$ of conc. $\mathrm{HNO}_{3}$ acid. The samples were shaken thoroughly and placed in an ice box. Field parameters $(\mathrm{pH}$, EC, TDS, Temp,) were measured for the springs and river samples using $\mathrm{pH}, \mathrm{EC}$, TDS meters (Hanna instruments, H1 9811) and a digital thermometer. The water samples were analyzed for major cations and anions at the Institute of Agronomic Research and Development (IRAD) in Ekona, SW Region of Cameroon.
The concentrations of $\mathrm{Na}^{+}, \mathrm{K}^{+}$, and $\mathrm{Ca}^{2+}$, were determined using the Gallemkamp flame photometer. $\mathrm{Mg}^{2+}$, $\mathrm{NO}_{3}^{-}, \mathrm{SO}_{4}^{2-}, \mathrm{NH}_{4}^{+}, \mathrm{PO}_{4}^{3-}$ were analyzed by Colorimetry and $\mathrm{HCO}_{3}^{-}$and $\mathrm{Cl}^{-}$by titration.

The major oxides and few trace elements in volcanic materials have been used to characterize the volcanic rocks and compute the enrichment and depletion of elements. Major cations and anions in water are used to do the aqueous speciation calculations to determine saturation indices (SI) using PHREEQC [17].

Field data and geochemical data are used together with satellite images to produce geologic maps and models using GLOBAL MAPPER and SURFER 9 software which further highlight the spatial distribution of volcanic materials, springs and rivers.

\section{Results}

\subsection{Geospatial Distribution of Rock Types}

A 1:500 geologic map of the study area drawn using combined field and satellite imagery data with GLOBAL MAPPER 11 and SURFER 9 software reveals that the area has five main rock types, namely, Trachytic, Rhyolitic, Basaltic, Tuff breccia/pyroclastic breccia, and Volcanic debris flow (Figure 2). The crystalline rocks are more or less fresh but the debris flow has suffered intense chemical weathering. The debris flow has an estimated perimeter of $14884.4 \mathrm{~m}$ and area of $7175.5 \mathrm{~m}^{2}$. The bulk of the material is a mixture of fresh aphanetic rock fragments with very fine grain friable material in the ratio 1:3. The overall texture is volcaniclastic and many radial cracks are present qualifying the outcrop as a lahar (Figure 3(a)). Rounded clayey aggregates also constitute large parts of these outcrops. These sections of the flow are at relatively high topography at about $1650-1700 \mathrm{~m}$ or more above sea level.

The river Nkambie has exposed steep walls about 50 $60 \mathrm{~m}$ high of sections of the debris flow (Figures 3(a)-(e)). The wall shows a viscoplastic rheology and abundant sub-rounded boulders at the bottom. The outcrop is predominantly made up of volcaniclastic material. The remainder is made up of huge volumes of precipitates occurring at the bottom of the exposed wall. A pure white soft precipitate with acicular and feathery habit and a taste peculiar to bicarbonate salts occupies the interstices of the sub rounded boulders (Figure 3(b)). Another dull yellow precipitate with an earthly to massive habit, a sweetish astringent taste and a slight sulphurous odor is also dominant (Figure 3(e)). Most of the samples effervesce on the addition of $\mathrm{HCl}$. This bottom section is relatively at lower topography (1450 - $1500 \mathrm{~m}$ above sea level). SURFER generated DEM combined with the geologic map shows that the main river (Nkambie) flows through the base of the debris flow where appreciable 

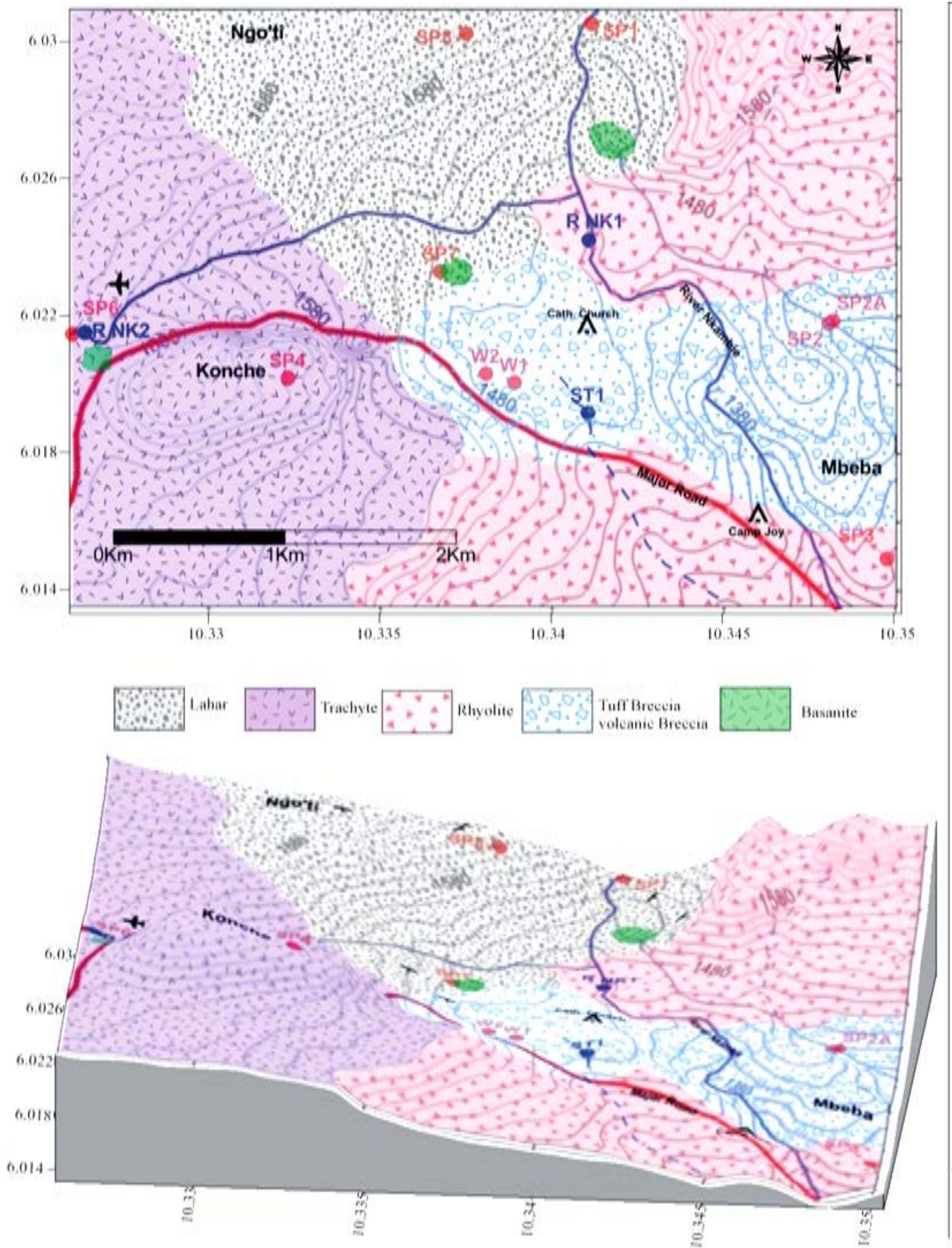

Figure 2. Geospatial data added on the topographic design (geologic map) both in $2 \mathrm{D}$ and 3D for the study area. The main rock types are classified using field classifications [18-22] and other identification parameters. 


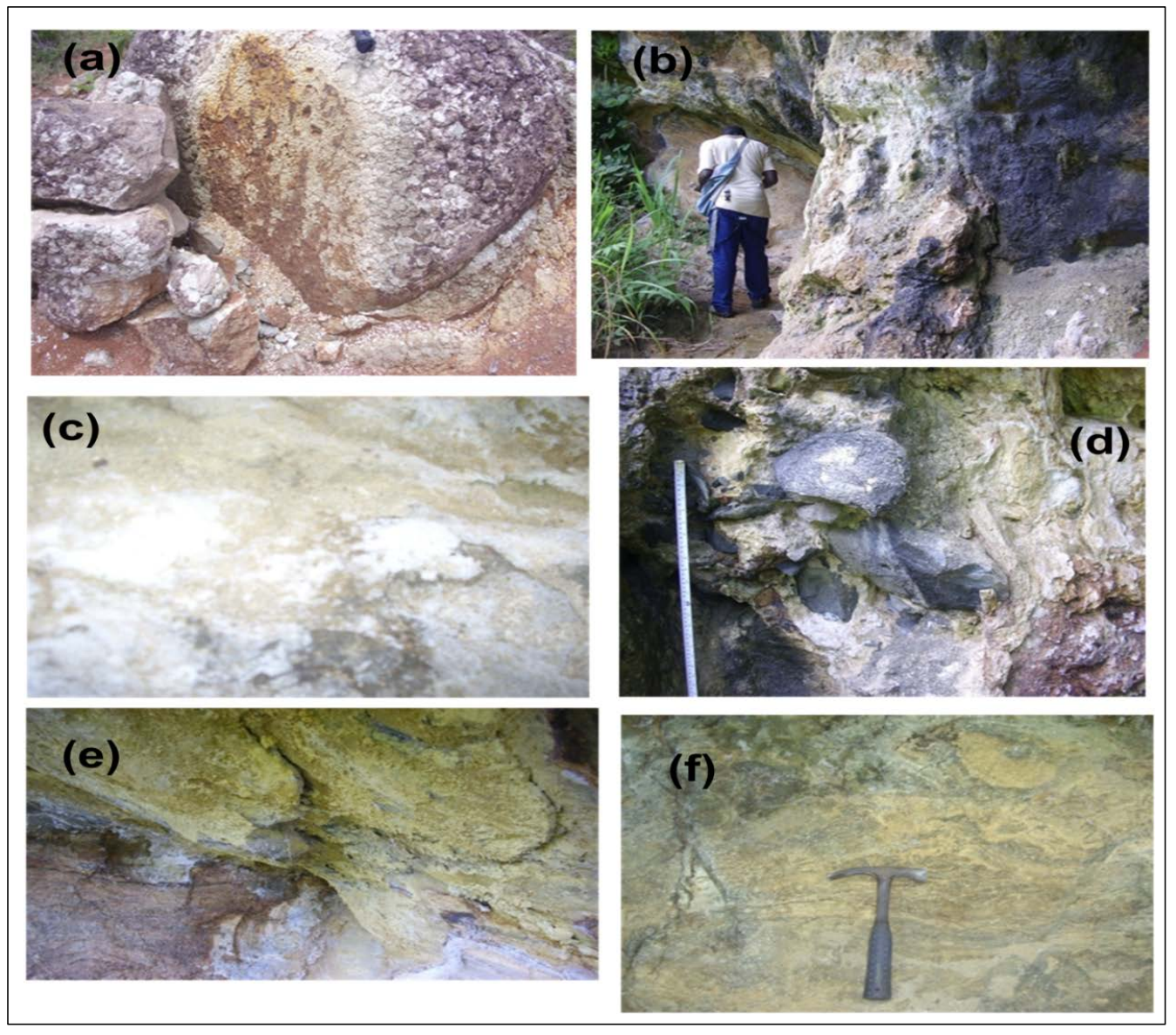

Figure 3. (a)-(e): Bottom sections of a debris flow in Sabga. (a) Outcrops of volcanic debris flow showing fragments of rocks in a fine grained matrix that has been weathered. (b) Bottom section of a volcanic debris flow. The upper section above is about $60 \mathrm{~m}$ on average. (c) Saline precipitates on the bottom section of the lahar. (d) Basaltic boulders cemented by carbonate material. (e) Yellow precipitates occurring with the white precipitates. (f) Evidence of plastic rheology which characterizes debris flow.

secondary precipitation and salts have been observed (Figure 2).

\subsection{Characterization of Volcanic Rock and Weathered Volcanic Debris}

The volcanic rocks are geochemically classified on the Harker diagram using the Total Alkali $\left(\mathrm{Na}_{2} \mathrm{O}+\mathrm{K}_{2} \mathrm{O}\right)$ vs. Silica $\left(\mathrm{SiO}_{2}\right)$ classification (TAS) [22], as Basanite/ Trachy-basalt, Phonolite, Trachyte/Trachydacite and Rhyolites (Figure 4). $\mathrm{SiO}_{2}$ concentrations range from $47 \%$ - 73.31\%, while concentrations of $\mathrm{Al}_{2} \mathrm{O}_{3}$ range from $11.93 \%$ - 20.49\%. $\mathrm{CaO}$ concentrations range from $0.136 \%-9.86 \%$ and $\mathrm{MgO}$ range from $0.103-4.55 . \mathrm{Na}_{2} \mathrm{O}$ and $\mathrm{K}_{2} \mathrm{O}$ concentrations range from $2.227-6.534$ and 2.22 - 6.776 respectively.

Incompatible trace elements (LIL, HFSEs), Rb, Nb, Zr, $\mathrm{Y}$, and $\mathrm{Zn}$ are present with $\mathrm{Nb}$ and $\mathrm{Zr}$ having the highest frequency of occurrence in the samples. The major oxide chemistry is presented in Table 1.

Comparing the major oxide chemistry of volcanic

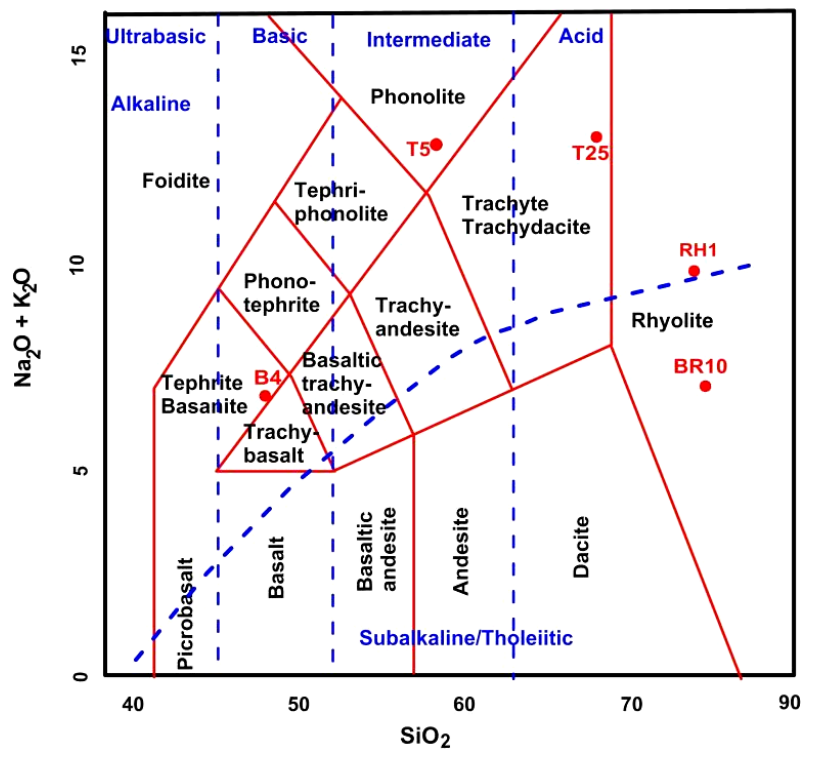

Figure 4. Classification of Sabga volcanic rocks on TAS diagram [22]. 
Table 1. Major oxides, normative mineralogy and trace element concentrations in volcanic rocks.

\begin{tabular}{|c|c|c|c|c|c|}
\hline Sample code & B4 & BR10 & T5 & RH1 & T25 \\
\hline $\mathrm{SiO}_{2}$ & 47 & 73.21 & 56.98 & 72.66 & 67.28 \\
\hline $\mathrm{TiO}_{2}$ & 3.264 & 0.316 & 0.679 & 0.616 & 0.389 \\
\hline $\mathrm{Al}_{2} \mathbf{O}_{3}$ & 15.71 & 16.1 & 20.49 & 12.02 & 11.93 \\
\hline $\mathrm{Fe}_{2} \mathrm{O}_{3} \mathbf{t}$ & 11.38 & 0.6869 & 7.014 & 2.833 & 5.811 \\
\hline MnO & 0.19 & 0.0794 & 0.143 & 0.01 & 0.106 \\
\hline MgO & 4.551 & 0.32 & 0.103 & 0.35 & 0.38 \\
\hline $\mathrm{CaO}$ & 9.86 & 0.434 & 0.49 & 0.136 & 0.371 \\
\hline $\mathrm{Na}_{2} \mathrm{O}$ & 4.311 & 2.27 & 6.534 & 4.485 & 6.106 \\
\hline $\mathbf{K}_{2} \mathbf{O}$ & 2.22 & 4.633 & 6.075 & 5.061 & 6.776 \\
\hline $\mathbf{P}_{2} \mathbf{O}_{5}$ & 0.645 & & & 0.041 & 0.128 \\
\hline $\mathrm{SO}_{2}$ & 0.116 & 0.0693 & & 0.0221 & 0.0334 \\
\hline LOI & 0.76 & 1.89 & 1.51 & 1.8 & 0.69 \\
\hline SUM & 100.007 & 100.0086 & 100.018 & 100.0341 & 100.0004 \\
\hline \multicolumn{6}{|l|}{ CIPW NORM } \\
\hline $\mathbf{Q}$ & & 40.868 & & 29.058 & 21.104 \\
\hline C & & 6.562 & 2.274 & & \\
\hline Or & 13.12 & 27.38 & 35.901 & 29.909 & 40.044 \\
\hline Ab & 30.292 & 19.208 & 43.499 & 33.648 & 23.637 \\
\hline An & 16.958 & 2.153 & 2.431 & & \\
\hline Ne & 3.352 & & 6.387 & & \\
\hline Ns & & & & 1.001 & 6.524 \\
\hline Di & 13.326 & & & & 0.051 \\
\hline Нy & & 0.797 & & 0.872 & 0.923 \\
\hline Ol & 3.614 & & 0.18 & & \\
\hline Il & 0.406 & 0.17 & 0.306 & 0.021 & 0.227 \\
\hline Tn & & & & 0.287 & 0.662 \\
\hline Pf & 5.193 & & & & \\
\hline $\mathbf{R u}$ & & 0.227 & 0.518 & 0.488 & \\
\hline Ap & 1.528 & & & 0.097 & 0.303 \\
\hline Sum & 87.789 & 97.364 & 91.496 & 95.382 & 93.474 \\
\hline DI & 46.764 & 87.456 & 85.787 & 92.618 & 84.606 \\
\hline Mg\# & 30.76455 & 34.1075 & 1.605462 & 12.07021 & 6.773739 \\
\hline $\mathbf{R b}$ & & 81 & 190 & & 251 \\
\hline Ba & & 794 & & & \\
\hline Nb & 69 & 86 & 424 & 226 & 425.9 \\
\hline $\mathrm{Sr}$ & 969.4 & & & & \\
\hline $\mathbf{Z r}$ & 319 & 555.6 & 2139 & 1017 & 2864 \\
\hline $\mathbf{Y}$ & & 52 & 36 & 88 & 77 \\
\hline Ga & & & 50 & 40 & 49 \\
\hline $\mathbf{V}$ & 198 & & & & \\
\hline $\mathrm{Cr}$ & 267 & & & & \\
\hline $\mathbf{C u}$ & 70 & & & & \\
\hline $\mathbf{Z n}$ & & 66 & 363 & 124 & 183 \\
\hline Ce & & & & & 530 \\
\hline
\end{tabular}

rocks of Sabga with some rocks in other parts of the world e.g. comparison of sample B4 and the alkali olivine basalt sample KLPA-1, of Molokai volcano, Hawaii
[23] and RH1 with Circle Creek rhyolite, sample 60NC145, Nevada [24], has shown almost the same chemistries. No peculiarities are presented by the Sabga volcanic rocks.

The $\mathrm{Mg}$ numbers $(\mathrm{Mg} \#=\mathrm{MgO} / \mathrm{MgO}+\mathrm{FeO})$ with $\mathrm{FeO}$ calculated as $0.9 \mathrm{Fe}_{2} \mathrm{O}_{3} \mathrm{t}$ range from $1.605 \%-30.765 \%$ with an average of 17.064 .

Norms are computed from the major oxides using CIPW normative mineral calculations [25,26], giving hypothetical mineral phases that might be present in the volcanic rocks.

Differentiation index (DI) calculated from norms as the sum of $\mathrm{Q}+\mathrm{Or}+\mathrm{Ab}+\mathrm{Ne}$ [27] show that DI range from 46.764 - 92.6 with an average of 79.44. Normative minerals include quartz, corundum, orthoclase, albite, anorthite, nepheline, nosean, diopside, hypesthene, olivine, ilmenite, titanite, perovskite, rutile and apatite (Table 1). Normative quartz, orthoclase and albite dominate meanwhile normative anorthite is in lesser percentages. Other mineral phases containing $\mathrm{CaO}$ such as Diopside, Hypersthene, perovskite, and titanite occur in very small concentrations.

Weathered volcanic material and secondary precipitates all parts of a single volcanic debris flow produce major oxides essentially similar to the oxides in the fresh volcanic rocks (Table 2). The concentrations of the oxides vary especially in the precipitates but the weathered materials at higher topography (CL1) have $\mathrm{SiO}_{2}$ and $\mathrm{Al}_{2} \mathrm{O}_{3}$ concentrations of $70.01 \%$ and $11.3 \%$ and these are similar with those of the fresh rhyolite (RH1).

$\mathrm{K}_{2} \mathrm{O}$ concentrations are equally similar but there is a marked reduction of about $92.7 \%$ in the concentration of $\mathrm{Na}_{2} \mathrm{O}$. Ash and precipitates at the base of the volcanic debris have very high concentrations of $\mathrm{CaO}(32.4 \%$ average), $\mathrm{SO}_{2}(11.5 \%)$ and very low concentrations of $\mathrm{SiO}_{2}$ (17.91\% average), though the base ash (ASH B) has a $\mathrm{SiO}_{2}$ concentration of $60.3 \%$ similar to that of fresh intermediate trachytic rocks. $\mathrm{CaO}$ concentrations in some of the precipitates (SIL, SAL1) are higher than those commonly found in limestones.

$\mathrm{Fe}_{2} \mathrm{O}_{3} \mathrm{t}$ and $\mathrm{SO}_{2}$ are high (16.13 and 45.99 respectively). These precipitates and bottom volcanic ash are also characterized by high losses on ignition of average $25.9 \%$.

\subsection{Estimating Element Losses and Gains from Fresh and Weathered Volcanic Materials}

The lahar (Figure 3) has been studied as a zone of intense weathering and leaching of material. To estimate major losses and gains in elemental concentrations, an enrichment and depletion diagram (Figure 5) is used. The following assumptions are made in the calculation:

> The volcanic debris is considered as heterolithologic consisting of all the primary rock types present in the area. 
Table 2. Major oxides and trace element concentrations in weathered volcanic materials and secondary precipitates.

\begin{tabular}{|c|c|c|c|c|c|}
\hline & CL1 & SIL & SAL1 & SAL 3Y & ASH B \\
\hline $\mathrm{SiO}_{2}$ & 70.01 & 1.51 & 3.68 & 6.11 & 60.34 \\
\hline $\mathrm{TiO}_{2}$ & 0.272 & 0.023 & 0.49 & 0.27 & 0.675 \\
\hline $\mathbf{A l}_{2} \mathbf{O}_{3}$ & 11.3 & 0.314 & 1.2 & 2.17 & 5.733 \\
\hline $\mathrm{Fe}_{2} \mathrm{O}_{3} \mathrm{t}$ & 3.884 & 0.253 & 4.235 & 16.13 & 5.244 \\
\hline MnO & 0.0557 & 0.165 & 0.121 & 0.0697 & 0.194 \\
\hline MgO & & 0.652 & & & 0.403 \\
\hline $\mathrm{CaO}$ & 0.473 & 54.7 & 61.31 & 6.894 & 6.842 \\
\hline $\mathrm{Na}_{2} \mathrm{O}$ & 0.328 & 0.472 & & & 3.28 \\
\hline $\mathbf{K}_{2} \mathbf{O}$ & 5.971 & 0.136 & 0.775 & 2.076 & 3.675 \\
\hline $\mathbf{P}_{2} \mathbf{O}_{5}$ & & 0.015 & 0.13 & 0.19 & 0.0928 \\
\hline $\mathrm{SO}_{2}$ & 0.042 & 0.05 & 0.128 & 45.99 & 0.013 \\
\hline LOI & 7.7 & 41.72 & 27.94 & 20.11 & 13.54 \\
\hline SUM & 100.0357 & 100.01 & 100.009 & 100.0097 & 100.0318 \\
\hline $\mathbf{R b}$ & 1055 & & & & 70 \\
\hline Nb & 202 & & & & 30 \\
\hline $\mathrm{Sr}$ & & 835.7 & 267 & 40 & 130 \\
\hline $\mathrm{Zr}$ & 1255 & 14 & 204 & 92 & 208 \\
\hline $\mathbf{Y}$ & 235 & & & & \\
\hline Ga & 50 & & & & \\
\hline Zn & 349 & & 120 & 70 & 99 \\
\hline $\mathbf{L a}$ & 560 & & & 0 & \\
\hline Tb & & & & 55 & \\
\hline
\end{tabular}

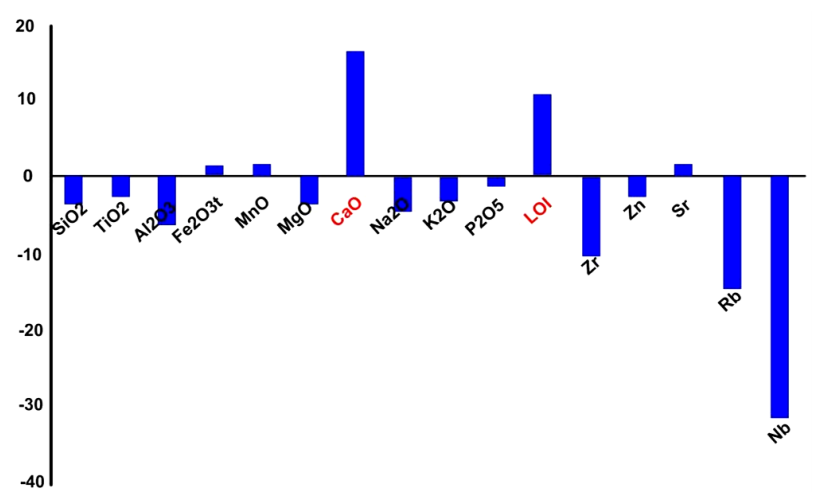

Figure 5. Enrichment depletion diagram for average compositions of fresh and weathered volcanic rocks/precipitates.

$>$ The average composition of all the fresh rock types is considered as the original debris irrespective of the grain size.

$>$ The material at the top of the lahar, though weathered is considered together with the fresh rocks because of its chemical similarity with rhyolites.

$>$ The average chemistry of all the material at the bottom of the debris flow is calculated.
The difference in magnitude when the two sets of averages (major and trace elements) are considered as ratios is calculated as the depletion (negative) or as enrichment (positive).

$\mathrm{CaO}$ is seen to have been enriched up to 16.54 times its original average value of about 1.96 while LOI has been enriched 10.88 its original average value (2.37). $\mathrm{Fe}_{2} \mathrm{O}_{3} \mathrm{t}, \mathrm{MnO}$, and $\mathrm{Sr}$ have also been enriched at the base of the lahar but in lesser amounts (Figure 5).

High loss on ignition is related to high carbonate, bicarbonate and sulphate ions associated with secondary precipitation at the bottom of the lahar.

\subsection{Hydrochemistry of Springs and Rivers}

The hydrochemical data (Table 3 ) reveal that the dominant major cation is $\mathrm{Ca}^{2+}$, followed by $\mathrm{K}^{+}$for the brackish-saline water springs and rivers. $\mathrm{Mg}^{2+}$ dominates as second main cation for the fresh water springs. The anions are in the order $\mathrm{HCO}_{3}^{-}>\mathrm{SO}_{4}^{-}>\mathrm{Cl}^{-}$for the brackish-saline water springs and $\mathrm{HCO}_{3}^{-}>\mathrm{Cl}^{-}>\mathrm{SO}_{4}^{-}$ for the fresh water springs and rivers. The total cations $\left(\mathrm{TZ}^{+}\right)$and total anions ( $\mathrm{TZ}^{-}$) range from 20.09 - 917.72 $\mathrm{mg} / \mathrm{l}$ and 20.83 - 12,292.32 $\mathrm{mg} / \mathrm{l}$ respectively, resulting in averages of 251.87 and $2971.9 \mathrm{mg} / \mathrm{l} \mathrm{Ca}^{2+}$ constitutes on average $65.21 \%$, of the total cations in meq/l while $\mathrm{Mg}^{2+}$ and $\mathrm{Na}^{+}+\mathrm{K}^{+}$contribute $21.33 \%$ and $13.45 \%$ respectively. $\mathrm{HCO}_{3}^{-}$constitutes averagely $76.75 \%$ of the total anions in meq/l while $\mathrm{Cl}$ and $\mathrm{SO}_{4}{ }^{=}$contribute $19.26 \%$ and $3.98 \%$ respectively. Anomalous concentrations especially of $\mathrm{Ca}^{2+}, \mathrm{K}^{+}, \mathrm{HCO}_{3}^{-}$and $\mathrm{SO}_{4}^{-}$are associated with springs labeled SP1, SP2A, SP7, W1 and W2. The percentage of $\mathrm{Ca}^{2+}$ increases further to an average of $71.55 \%$ and $\mathrm{HCO}_{3}^{-}$to an average of $92.16 \%$ in the highly concentrated springs. There is a great variation between the cations and anions. Resulting in negative ion balances (-65 to -92.2 ) in the highly bicarbonate concentrated springs. TDS as high as 5188.8 - 11,570.2 mg/l classify the highly concentrated spring water as brackish to saline [28]. Piper diagram (Figure 6) places the water into $\mathrm{Ca}+$ $\mathrm{Mg}-\mathrm{HCO}_{3}+\mathrm{CO}_{3}$ and $\mathrm{HCO}_{3}+\mathrm{CO}_{3}$ hydrochemical facies [29]. The water from both the rivers and the springs straddle the Ca- Mg apex of the major cation triangular plot in Figure 6. This shows the presence of an important $\mathrm{Ca}^{2+}$ and $\mathrm{Mg}^{2+}$ source in the area. This signature is different from those of springs along the CVL with $\mathrm{Na}^{+}$and $\mathrm{K}^{+}$signatures interacting with almost the same rocks (intermediate-acid) like those found in Sabga. This might be signifying another origin other than the intense watersilicate-rich rock interaction [30] we will expect in areas with acid rich rocks; where the major cations generally cluster around the $\mathrm{Na}^{+}$and $\mathrm{K}^{+}$apex of triangular plots.

$\mathrm{Na}^{+}$normalized molar ratios [31] are calculated and presented in Table 4 and summarized in Figure 7. It should be noted that these values for rivers were not cor- 
Table 3. Sample location points, summary of the hydrochemistry and field parameters (EC, TDS, pH, Temp) of springs (1st ten) and rivers (last three).

\begin{tabular}{|c|c|c|c|c|c|c|c|c|c|c|c|c|c|c|c|c|c|c|c|c|}
\hline & Long. & Lat & Elevation & $\begin{array}{l}\mathrm{Na}^{+} \\
(\mathrm{mg} / \mathrm{l})\end{array}$ & $\mathrm{K}^{+}$ & $\mathrm{Ca}^{2+}$ & $\mathrm{Mg}^{2+}$ & $\mathrm{Cl}^{-}$ & $\mathrm{HCO}^{3-}$ & $\mathrm{SO}_{4}^{2-}$ & $\mathrm{NO}^{3-}$ & $\mathrm{NH}^{4+}$ & $\mathrm{HPO}_{4}^{2-}$ & $\mathrm{TZ}^{+}$ & $\mathrm{TZ}$ & IB & $\begin{array}{c}\text { EC } \\
(\mu \mathrm{s} / \mathrm{cm})\end{array}$ & $\begin{array}{l}\text { TDS } \\
(\mathrm{mg} / \mathrm{l})\end{array}$ & $\mathrm{pH}$ & $\begin{array}{c}\text { Temp } \\
\left({ }^{\circ} \mathrm{C}\right)\end{array}$ \\
\hline SP1 & 10.3 & 6.03052 & 1518 & 6.92 & 60.45 & 240.8 & 8.51 & 8 & 4782 & 82.13 & 0.67 & & 0.1 & 65.99 & 4954.93 & -69.3 & 7744.5 & 5188.8 & 7.1 & 20.3 \\
\hline SP2A & 10.3481 & 6.02177 & 1389 & 5.91 & 44.07 & 185.4 & 4.97 & 24 & 3050 & 64.64 & 0.13 & & 0.06 & 430.72 & 3203.41 & -65 & 5043.3 & 3379 & 7.4 & 22.1 \\
\hline SP2 & 10.34824 & 6.02185 & 1389 & 0.41 & 5.46 & 18.6 & 6.54 & 8 & 43 & 1.79 & 0.02 & & 0.79 & 56.15 & 54.6 & 25.3 & 125.1 & 83.8 & 7.2 & 21 \\
\hline SP3 & 10.34981 & 6.01488 & 1322 & 0.21 & 2.73 & 11.2 & 6.75 & 9 & 20 & 0.48 & & 0.97 & 0.08 & 38.84 & 29.96 & 33.7 & 75.2 & 50.4 & 8 & 24.2 \\
\hline SP4 & 10.33232 & 6.02016 & 1680 & 0.21 & 2.34 & 7.4 & 4.78 & 12 & 29 & & 0.02 & & 0.13 & 26.91 & 41.02 & 1.1 & 83.1 & 55.7 & 6.4 & 20.6 \\
\hline SP6 & 10.32604 & 6.021451 & 1657 & 0.23 & 3.51 & 11.2 & 0.57 & 9 & 23 & 0.21 & & & 0.24 & 27.28 & 32.42 & 5.2 & 71.2 & 47.7 & 6.8 & 18.9 \\
\hline SP7 & 10.33678 & 6.02327 & 1477 & 7.98 & 65.52 & 27.8 & 8.32 & 12 & 6015 & 72.49 & 0.09 & & 1.29 & 145.7 & 6172.07 & -92.2 & 9267.3 & 6209.1 & 7.7 & 19.7 \\
\hline SP8 & 10.33 & 6.030219 & 1604 & 0.23 & 3.12 & 14.8 & 6.75 & 5 & 41 & 2.13 & 0.47 & 0.48 & & 46.45 & 50.73 & 23.5 & 108.9 & 73 & 7.9 & 20.1 \\
\hline W2 & 10.33893 & 6.02003 & 1457 & 13.25 & 97.89 & 370.6 & 32.69 & 156 & 9248 & 1064.26 & & 0.34 & 2.41 & 917.72 & 11532.5 & -76 & 16392.1 & 10982.7 & 8.6 & 23.3 \\
\hline W1 & 10.33809 & 6.02029 & 1449 & 13.25 & 96.72 & 370.6 & 14.24 & 184 & 9675 & 1216.39 & 0.56 & & 1.37 & 879.65 & 12292.3 & -78.6 & 17269.0 & 11570.2 & 7.87 & 21.6 \\
\hline ST1 & 10.34108 & 6.01915 & 1459 & 0.85 & 7.8 & 33.4 & 8.15 & 9 & 201 & 6.2 & 0.71 & 1.26 & 0.12 & 91.75 & 223.11 & -17.7 & 397.6 & 266.4 & 7.6 & 18.9 \\
\hline RNK & 10.34111 & 6.02419 & 1446 & 0.25 & 2.34 & 11.2 & 1.07 & 6 & 12 & 0.9 & 1.03 & & & 27.13 & 20.83 & 30.2 & 50.4 & 33.8 & 7.6 & 18.1 \\
\hline RNK2 & 10.32582 & 6.021451 & 1663 & 0.12 & 1.95 & 7.4 & 1.61 & 5 & 22 & & 0.98 & 0.24 & & 20.09 & 27.98 & 5.2 & 56.8 & 38.1 & 8.6 & 18.4 \\
\hline
\end{tabular}

Table 4. $\mathrm{Na}^{+}$normalized molar ratios for Sabga spring and river water.

\begin{tabular}{ccccccc}
\hline & $\mathbf{K}^{+} / \mathbf{N a}$ & $\mathbf{C a}^{+} / \mathbf{N a}$ & $\mathbf{M g} / \mathbf{N a}$ & $\mathbf{H C O}_{3} / \mathbf{N a}$ & $\mathbf{S O}_{4} / \mathbf{N a}$ & $\mathbf{C l}^{-} / \mathbf{N a}$ \\
\hline SP1 & 5.136324 & 19.96005 & 1.162994 & 259.9827 & 2.840482 & 0.749733 \\
SP2A & 4.384477 & 17.99424 & 0.795285 & 194.1571 & 2.617642 & 2.63358 \\
SP2 & 7.830167 & 26.02198 & 15.08509 & 39.45713 & 1.044878 & 12.65403 \\
SP3 & 7.643734 & 30.59215 & 30.39754 & 35.8304 & 0.547039 & 27.79367 \\
SP4 & 6.551772 & 20.21267 & 21.52596 & 51.95407 & & 37.05823 \\
SP6 & 8.973079 & 27.93196 & 2.343695 & 37.62192 & 0.218518 & 25.37683 \\
SP7 & 4.827621 & 1.998265 & 0.985994 & 283.5787 & 2.17406 & 0.975217 \\
SP8 & 7.97607 & 36.91009 & 27.75428 & 67.06515 & 2.2164 & 14.09824 \\
W2 & 4.343948 & 16.04356 & 2.333206 & 262.5868 & 19.22331 & 7.635394 \\
W1 & 4.292029 & 16.04356 & 1.016361 & 274.711 & 21.97118 & 9.005849 \\
ST1 & 5.395577 & 22.53922 & 9.067607 & 88.96476 & 1.745698 & 6.866672 \\
RNK1 & 5.503488 & 25.69741 & 4.047602 & 18.05852 & 0.861587 & 15.56446 \\
RNK2 & 9.554668 & 35.37217 & 12.68816 & 68.97351 & & 27.02163 \\
\hline
\end{tabular}

rected for atmospheric inputs because of the negligible concentrations in rain water. Average values for $\mathrm{Ca} / \mathrm{Na}$, $\mathrm{Mg} / \mathrm{Na}, \mathrm{HCO}_{3} / \mathrm{Na}$, and $\mathrm{Ca} / \mathrm{Mg}$ molar ratios are 22.87, $9.94,129.5$ and 7.5 respectively. These values are several magnitudes higher than the high values [31] for rivers/water draining basalts (Ca/Na: $0.2-3.15, \mathrm{HCO}_{3} / \mathrm{Na}$ : 1 - 10, Mg/Na: 0.15 - 3.15), though the $\mathrm{Mg} / \mathrm{Na}$ for the $\mathrm{HCO}_{3}$-concentrated springs reflect those for water draining basalts $\left(\mathrm{Mg}^{2+} / \mathrm{Na}: 0.15\right.$ - 3.15).

The $\mathrm{Na}^{+}$normalized plots show a trend which generally shifts towards and occupy the carbonate dissolution end and a general shift away from $\mathrm{Na}^{+}$(Figure 8). In comparison with the diagrams in [31], the springs with anomalously very high bicarbonates lie above the carbonate dissolution zone and can be considered as zones of bicarbonate concentration. It is also evident that these springs are less concentrated in $\mathrm{Mg}^{2+}$ relative to the other springs and rivers and have $\mathrm{Mg}^{+} / \mathrm{Na}^{+}$molar values within the range for water draining basalts. $\mathrm{Na}^{+}$normalized molar ratio trends for the brackish-saline springs (Figure 9) show a gradual concentration of springs down slope relative to their sampling point elevation.

The brackish-saline springs are supersaturated with certain mineral phases: SI of Aragonite (0.8 - 2.61), calcite (0.96 - 2.86), dolomite (1.7 - 5.0), and hydroxyl apatite $(0.16-8.62)$. Mineral saturation is presented in 


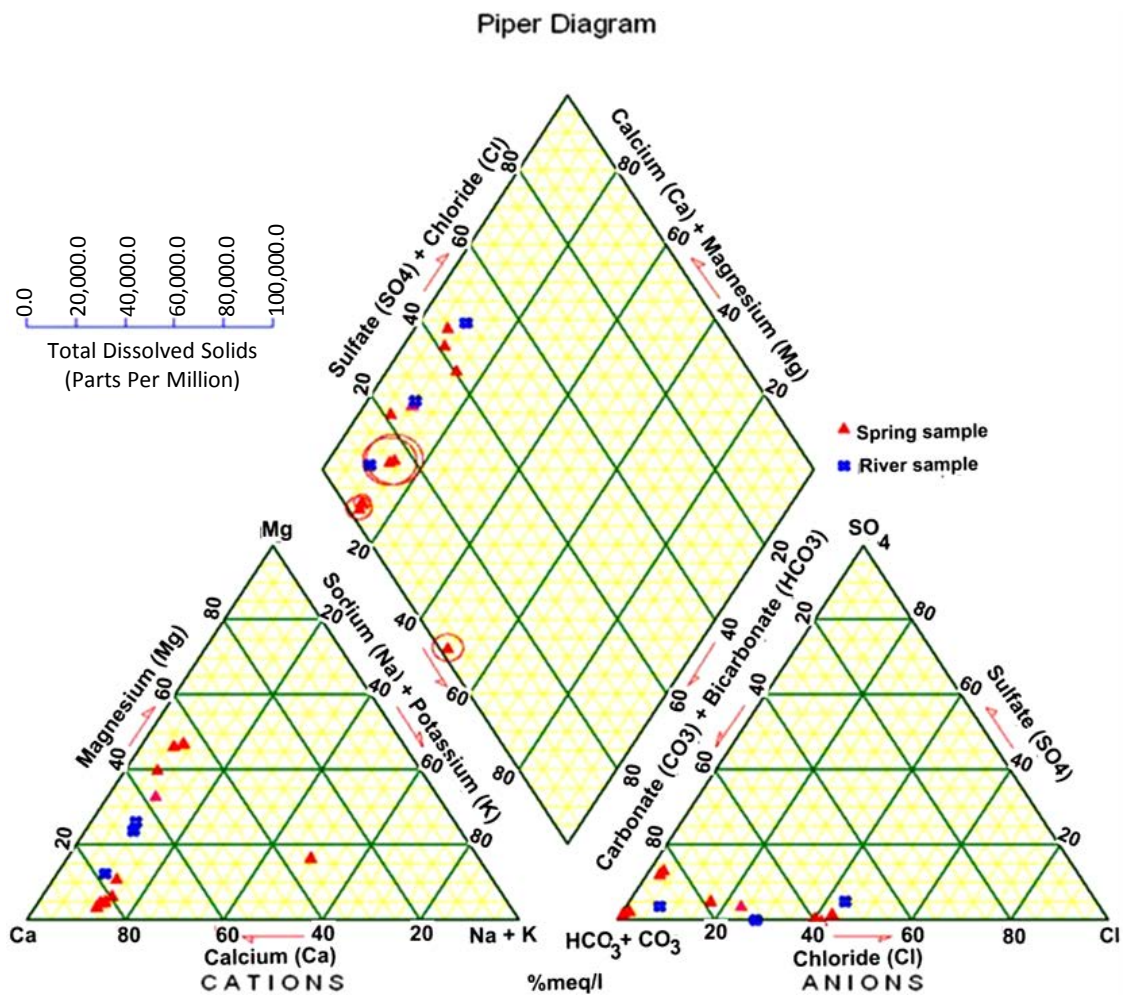

Figure 6. Piper diagrams for the Sabga spring/ river water samples showing the major hydrochemical facies after [29].

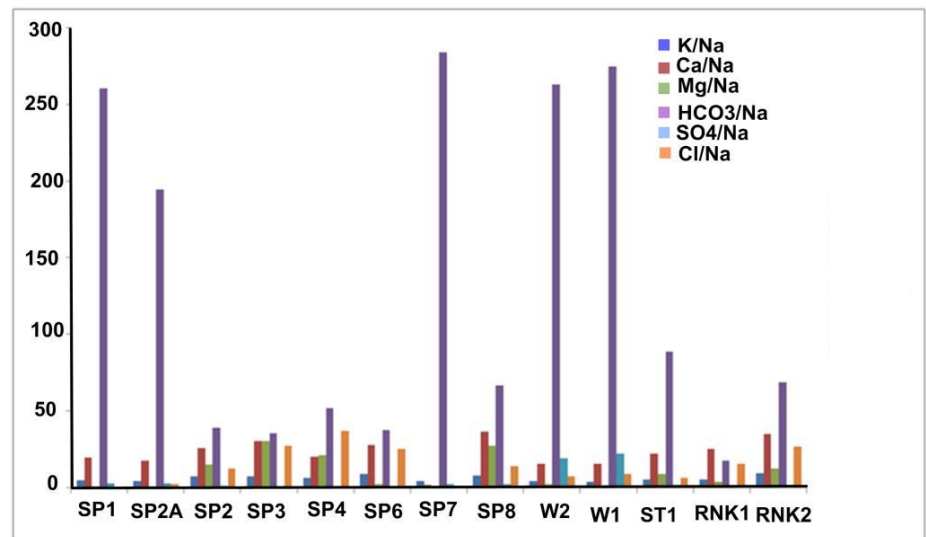

Figure 7. Histogram showing the Na normalized molar ratios for the spring and river water samples.

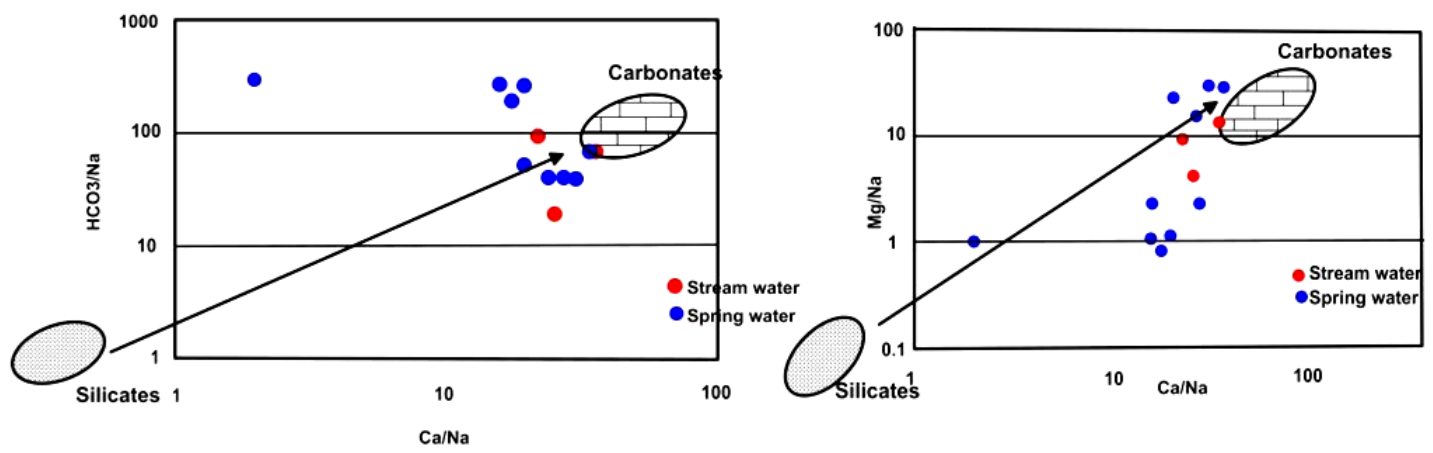

Figure 8. Na normalized molar ratio plots [31] for the spring and river water samples showing the important contribution of carbonate dissolution in modifying the chemistry of the springs and rivers. 


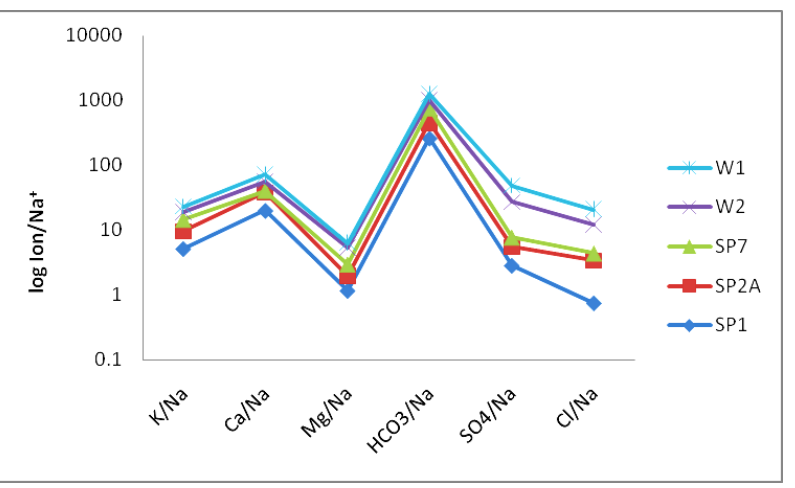

Figure 9. Concentration trend for the brackish/saline spring samples down gradient.

Table 5. The abundance of calcium oxide phases in the minerals is indicative of the dissolution of calcium carbonate rocks.

Plot of TDS vs $\mathrm{Na}^{+} / \mathrm{Na}^{+}+\mathrm{Ca}^{2+}$ (Figure 10) show a deviation of spring water samples from the three recharging contributions postulated for spring water chemistry [32]. Such a deviation supports one of the major outlined short comings [33] with the diagram, that there is no place for waters which have been affected by domestic contamination or other sources of hydrochemical enrichment outside of the three proposed sources.

\subsection{GIS/Hydrogeologic Models}

The concentrations of major ions considered as third coordinate axes are plotted in 3D, on the same longitude and latitude space (first two coordinates) used in generating the 3D topographic model and stacked on the later (Figure 11). The highest concentrations coincide with a geomorphic structure; a shallow volcanic maar.

\section{Discussion}

The geologic field mapping presents a volcanic area with volcanic domes and plugs characteristic of acid volcanism. The satellite image (Figure 1) confirms that the area is characterized by explosive volcanic activity due to the presence of the Foleshelle crater. The rock types are generally acid rocks with the trachytic rocks comprising about $34 \%$, rhyolitic about $24 \%$ and tuff breccia and basaltic rocks making $15 \%$ and $7 \%$ respectively. The northern slope of the area is made up of volcanic debris flow (lahar) material making up to $29 \%$ of the study area and is evidence of the explosive and strongly acidic nature of the Sabga lithologies [8]. The rock types studied are consistent with names mentioned [11,13] for rocks occurring in the Bamenda Mountains and also for those [14] in nearby Oku and Ndu. The trachytic plug, together with rhyolitic and basaltic outcrops present very little weathering (chemical decomposition) meanwhile the massive volcanic debris flow (lahar) has been weathered. Field stu-

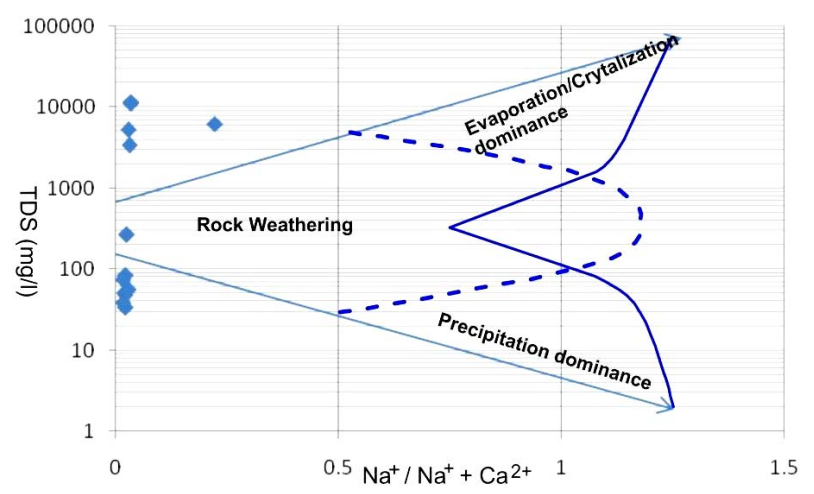

Figure 10. TDS vs. $\mathrm{Na}^{+} / \mathrm{Na}^{+}+\mathrm{Ca}^{2+}$ plot [32] of springs in the Sabga-Bamessing and environs.

dies also show that the debris is relatively weak as compared to the other rock types from the deep river valleys cut through by the Nkambie River (Figures 2 and 10). Where the river has been cut so deep, carbonates and salts are seen to precipitate from fluids seeping at the bottom of the debris. The saline springs (highly concentrated bicarbonate springs) are associated with very shallow circular marshy depressions and breccia (SP7, SP2A, $\mathrm{W} 1$, and W2) or occur and have an intimate connection with the bottom of the debris flow (SP1). Using spatial distribution of rock types and normative mineralogy, albite and orthoclase are dominant and by theory should dominate in the water chemistry. The dominance will be reflected in spring and river water draining this area as $\mathrm{Na}^{+}$and $\mathrm{K}^{+}$when considering the acid nature of the volcanic rocks. The dominance of $\mathrm{K}^{+}$and $\mathrm{Na}^{+}$has been studied in many fluids draining acid and intermediate rocks along the CVL [30]. The water chemistry has evolved showing a chemistry dominated by $\mathrm{Ca}^{2+}$ and $\mathrm{HCO}_{3}^{-}$. This evolved chemistry closely is consistent with the chemistry of the weathered materials and precipitates (high $\mathrm{CaO}$ and LOI) at the bottom of the debris flow. The carbonate character of some springs such as the Fossette spring along the CVL has been linked to the decomposition of volcanic ash [34]. In Sabga the region enriched in secondary carbonates might be a result of prolonged chemical weathering, resulting in element leaching and concentration. $\mathrm{HCO}_{3}^{-}$results exclusively from weathering [31]. High concentrations of $\mathrm{HCO}_{3}^{-}$in water result in concentration or enrichment of $\mathrm{Ca}^{2+}$ [35]. Although enriched, the same elements found in fresh volcanic rocks are represented in the enriched lithologies and saline precipitates in varying amounts supporting the idea of source rock isochemical dissolution [36]. The $\mathrm{Na}^{+}$ normalized molar ratio plots showing carbonate dissolution signature is a clear indication of a proximal calcium carbonate mineral source. This is further supported by the high SI values for Calcite, Aragonite and Dolomite computed using aqueous speciation calculations [17]. An enrichment process is therefore envisaged as a recharging 
Table 5. Saturation indices for mineral phases in the Sabga spring and river water computed using PHREEQC.

\begin{tabular}{|c|c|c|c|c|c|c|c|c|c|c|c|c|c|c|}
\hline San & Phases & SP1 & SP2A & SP2 & SP3 & SP4 & SP6 & SP7 & SP8 & W2 & W1 & ST1 & RNK1 & RNK2 \\
\hline \multirow{3}{*}{$\begin{array}{c}\text { Anhydrite } \\
\mathrm{CaSO}_{4}\end{array}$} & SI & -1.81 & -1.93 & -3.93 & -4.68 & I & -5.01 & -2.83 & -3.94 & -1.03 & -0.84 & -3.23 & -4.38 & I \\
\hline & $\log$ IAP & -6.16 & -6.28 & -8.28 & -9.04 & I & -9.35 & -7.18 & -8.29 & -5.38 & -5.18 & -7.57 & -8.72 & / \\
\hline & $\log \mathrm{KT}$ & -4.34 & -4.35 & -4.35 & -4.36 & I & -4.34 & -4.34 & -4.34 & -4.35 & -4.35 & -4.34 & -4.34 & / \\
\hline \multirow{3}{*}{$\begin{array}{c}\text { Aragonite } \\
\mathrm{CaCO}_{3}\end{array}$} & SI & 1.09 & 1.21 & -1.51 & -1.15 & -3.08 & -2.48 & 0.8 & -0.9 & 2.68 & 2.1 & -0.24 & -1.86 & -0.76 \\
\hline & $\log$ IAP & -7.22 & -7.11 & -9.82 & -9.48 & -11.39 & -10.78 & -7.49 & -9.2 & -5.65 & -6.21 & -8.54 & -10.16 & -9.06 \\
\hline & $\log \mathrm{KT}$ & -8.31 & -8.32 & -8.31 & -8.33 & -8.31 & -8.3 & -8.3 & -8.31 & -8.33 & -8.32 & -8.45 & -8.3 & -8.3 \\
\hline \multirow{3}{*}{ Calcite $\mathrm{CaCO}_{3}$} & SI & 1.24 & 1.35 & -1.36 & -1.01 & -2.93 & -2.33 & 0.96 & -0.75 & 2.82 & 2.25 & -0.09 & -1.71 & -0.61 \\
\hline & $\log$ IAP & -7.22 & -7.11 & -9.82 & -9.48 & -11.39 & -10.78 & -7.49 & -9.2 & -5.65 & -6.21 & -8.54 & -10.16 & -9.06 \\
\hline & $\log \mathrm{KT}$ & -8.45 & -8.46 & -8.46 & -8.47 & -8.46 & -8.45 & -8.45 & -8.45 & -8.47 & -8.46 & -8.45 & -8.44 & -8.45 \\
\hline \multirow{3}{*}{$\mathrm{CO}_{2}(\mathrm{~g})$} & SI & -0.56 & -1.01 & -2.64 & -3.7 & -2.23 & -2.6 & -1.02 & -3.32 & -1.75 & -1 & -2.36 & -3.57 & -4.29 \\
\hline & $\log$ IAP & -1.98 & -2.44 & -4.06 & -5.16 & -3.64 & -3.99 & -2.42 & -4.73 & -3.2 & -2.42 & -3.75 & -4.95 & -5.68 \\
\hline & $\log \mathrm{KT}$ & -1.41 & -1.43 & -1.42 & -1.46 & -1.41 & -1.39 & -1.4 & -1.14 & -1.45 & -1.43 & -1.39 & -1.38 & -1.39 \\
\hline \multirow{3}{*}{$\begin{array}{c}\text { Dolomite } \\
\mathrm{CaMg}\left(\mathrm{CO}_{3}\right)_{2}\end{array}$} & SI & 1.32 & 1.46 & -2.89 & -1.9 & -5.77 & -5.69 & 1.7 & -1.55 & 5 & 3.41 & -0.53 & -4.1 & -1.62 \\
\hline & $\log$ IAP & -15.66 & -15.56 & -19.8 & -18.97 & -22.75 & -22.63 & -15.27 & -18.53 & -12.05 & -13.6 & -17.48 & -21.12 & -18.55 \\
\hline & $\log \mathrm{KT}$ & -16.98 & -17.02 & -17 & -17.07 & -16.99 & -16.95 & -16.96 & -16.97 & -17.05 & -17.01 & -16.95 & -16.93 & -16.93 \\
\hline \multirow{3}{*}{$\begin{array}{c}\text { Gypsum } \\
\mathrm{CaSO}_{4}: 2 \mathrm{H}_{2} \mathrm{O}\end{array}$} & SI & -1.58 & -1.7 & -3.7 & -4.46 & / & -4.77 & -2.6 & -3.71 & -0.81 & -0.61 & -2.99 & -4.14 & I \\
\hline & $\log$ IAP & -6.16 & -6.28 & -8.28 & -9.04 & / & -9.35 & -7.18 & -88.29 & -5.39 & -5.19 & -7.57 & -8.72 & / \\
\hline & $\log \mathrm{KT}$ & -4.58 & -4.58 & -4.58 & -4.58 & / & -4.58 & -4.58 & -4.58 & -4.58 & -4.58 & -4.58 & -4.58 & / \\
\hline \multirow{3}{*}{$\mathbf{H}_{2}$ (g) } & SI & -22.2 & -22.8 & -22.4 & -24 & -20.8 & -21.6 & -23.4 & -23.8 & -25.2 & -23.74 & -23.2 & -23.2 & -25.2 \\
\hline & $\log$ IAP & -25.33 & -25.94 & -25.5 & -27.15 & -23.93 & -24.72 & -26.53 & -26.93 & -28.34 & -26.88 & -26.32 & -26.32 & -28.32 \\
\hline & $\log \mathrm{KT}$ & -3.13 & -3.14 & -3.13 & -3.15 & -3.13 & -3.12 & -3.13 & -3.13 & -3.14 & -3.14 & -3.12 & -3.12 & -3.12 \\
\hline \multirow{3}{*}{$\mathrm{H}_{2} \mathrm{O}$ (g) } & SI & -1.63 & -1.59 & -1.61 & -1.53 & -1.63 & -1.67 & -1.65 & -1.64 & -1.56 & -1.6 & -1.67 & -1.69 & -1.68 \\
\hline & $\log$ IAP & 0 & 0 & 0 & 0 & 0 & 0 & 0 & 0 & 0 & 0 & 0 & 0 & 0 \\
\hline & $\log \mathrm{KT}$ & 1.63 & 1.59 & 1.61 & 1.53 & 1.63 & 1.67 & -1.65 & 1.64 & 1.56 & 1.6 & 1.67 & 1.69 & 1.68 \\
\hline \multirow{3}{*}{ Halite $\mathrm{NaCl}$} & SI & -8.91 & -8.49 & -10.0 & -10.25 & -10.11 & -10.19 & -8.69 & -10.46 & -7.44 & -7.35 & -9.66 & -10.33 & -10.73 \\
\hline & $\log$ IAP & -7.34 & -6.91 & -8.44 & -8.67 & -8.54 & -8.62 & -7.12 & -8.89 & -5.86 & -5.78 & -8.09 & -8.76 & -9.16 \\
\hline & $\log \mathrm{KT}$ & 1.57 & 1.58 & 1.57 & 1.58 & 1.57 & 1.57 & 1.57 & 1.57 & 1.58 & 1.57 & 1.57 & 1.57 & 1.57 \\
\hline \multirow{3}{*}{$\begin{array}{l}\text { Hydroxylapatite } \\
\mathrm{Ca}_{5}\left(\mathrm{PO}_{4}\right)_{3} \mathrm{OH}\end{array}$} & SI & -0.6 & 0.16 & -0.32 & -0.28 & -9.24 & -5.15 & 0.71 & I & 8.62 & 5.65 & -0.11 & I & I \\
\hline & $\log$ IAP & -3.6 & -3 & -3.38 & -3.63 & -12.27 & -8.02 & -2.23 & I & 5.35 & 2.53 & -2.98 & / & I \\
\hline & $\log \mathrm{KT}$ & -3 & -3.16 & -3.06 & -3.34 & -3.02 & -2.87 & -2.94 & I & -3.27 & -3.12 & -2.87 & / & / \\
\hline \multirow{3}{*}{$\mathbf{O}_{2}(\mathrm{~g})$} & SI & -40.41 & -38.58 & -39.7 & -35.49 & -43.1 & -42.1 & -38.22 & -37.28 & -33.37 & -36.88 & -38.9 & -39.18 & -35.08 \\
\hline & $\log$ IAP & -43.26 & -41.45 & -42.6 & -38.38 & -45.96 & -44.94 & -41.07 & -40.13 & -36.25 & -39.74 & -41.74 & -42.02 & -37.92 \\
\hline & $\log \mathrm{KT}$ & -2.86 & -2.87 & -2.86 & -2.89 & -2.86 & -2.85 & -2.85 & -2.86 & -2.88 & -3.87 & -2.85 & -2.84 & -2.84 \\
\hline \multirow{3}{*}{$\mathrm{NH}_{3}(\mathrm{~g})$} & SI & I & I & I & -7.26 & I & I & I & -7.87 & -7.32 & I & -7.81 & / & -7.59 \\
\hline & $\log$ IAP & / & I & / & -5.47 & / & / & / & -6 & -5.52 & / & -5.92 & / & -5.69 \\
\hline & $\log \mathrm{KT}$ & I & I & I & 1.79 & I & I & I & 1.87 & 1.8 & I & 1.9 & I & 1.91 \\
\hline
\end{tabular}




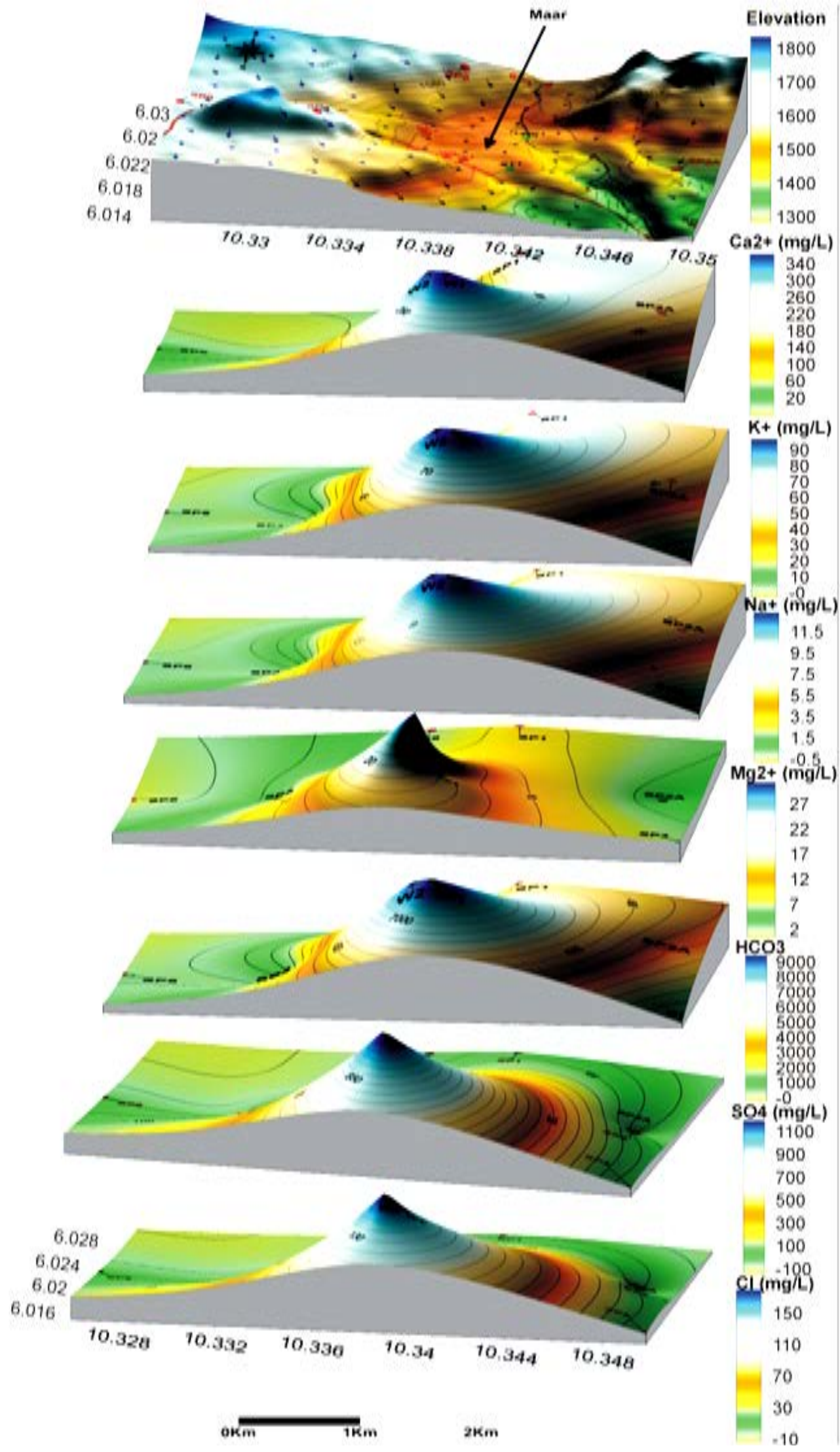

Figure 11. Major ion concentration stacked on 3D topographic design revealing the region of ion anomaly. 
contributor to water chemistry due a deviation from normal on the Gibbs diagram [32].

GIS and hydrogeologic models have contributed enormously in the present study and these are quoted amongst the best tools available used to characterize the environment [37-39]. The regenerated Digital Terrain Model (DTM) presents a real world object which is one of the objectives of 3D GIS [37]. Geospatial data on both 2D and 3D presentation reveals a true picture of the study area. The 3D representation brings a real picture where friable, porous volcanic debris flow material is weathered and the route of resultant chemical load can be hypothesized as being vertical. Groundwater flow vectors produced on the DTM show that the vectors are sub vertical to vertical and the ions must have followed the same pathway. The portion shown to be occupied by the volcanic debris flow extends on the slopes from about contour $1380 \mathrm{~m}$ to $>1720 \mathrm{~m}$ above sea level. Sections of the debris flow cut by the Nkambie River expose heights of about $90 \mathrm{~m}$ on average. Thickness in synergy with special lithology, weathering and removal of chemical load in vertical- sub vertical pathway across the entire profile of a volcanic debris flow might have led to a modified chemistry which is capable of precipitating salts. Secondary carbonate deposits precipitated at about contour $1550 \mathrm{~m}$ are considered a point source for the high concentrations of $\mathrm{Ca}^{2+}, \mathrm{K}^{+}, \mathrm{Na}^{+}, \mathrm{HCO}_{3}^{-}$, and $\mathrm{SO}_{4}^{2-}$ in some springs in the Sabga area.

Adjacent to the volcanic debris flow, the crystalline volcanic rocks are more in an intact stage and have undergone very little chemical weathering. It would rather be erroneous visualizing such a high input of salt- forming ions to result from these rocks.

The topographic model with geospatial data added also show how deep the river Nkambie has dug into the country rock. The ease of vertical erosion and the resultant steep and deep river valleys penetrate the zones of carbonate concentration and salt precipitation. The river thus acquires the carbonate-bicarbonate signatures also presented by the springs.

Hydrogeologic models defining the zone of anomaly for groundwater concentration show highest concentration at low topographic levels away from a high elevation source. The expected fate of the ions will be that ions disperse and loose their salinity unless another process causes them to concentrate.

The presence of a rim of tuff breccia surrounding a shallow depression as shown in the topographic and geologic maps both in 2D and 3D supports the presence of a maar. The peak in groundwater ion concentration coincides with this local explosion structure.

\section{Conclusions}

As opposed to the chemistry of fluids in parts of the CVL interacting with acid to intermediate volcanic rocks, the Sabga fluids (springs and rivers) have adopted a carbonate dissolution signature. Carbonate enrichment at the base of a volcanic debris flow is in line with the carbonate signatures adopted by the fluids. High salinity (TDS) in fluids of the Sabga is linked to bicarbonate salts precipitated from volcanic ash material at the base of volcanic debris flow.

High concentrations in salinity south of this ion rich point source (lahar) are associated with a local maar acting as a sink for elements.

This geologic spectacle whereby high salinities have developed in a purely volcanic environment might be linked to the following:

- Explosive volcanic activity leading to the formation of volcanic ash debris flows.

- Massive thickness of the debris and associated structures such as cracks.

- Intense weathering and leaching resulting in $\mathrm{Ca}^{2+}$ and $\mathrm{HCO}_{3}^{-}$enrichment.

- Carbonate/bicarbonate-mineral dissolution by rivers and springs.

- Structural control which further concentrates the $\mathrm{Ca}^{2+}$, $\begin{array}{lll}\mathrm{HCO}_{3}^{-} & \mathrm{SO}_{4}^{2-} & \text { and other ions. }\end{array}$

\section{Acknowledgements}

This article is a part of a M.Sc. thesis on water rock interaction at the University of Buea by VRB. We acknowledge the support and contributions of colleagues at the University over the years. The editorial comments of the editor are highly appreciated.

\section{REFERENCES}

[1] E. Njonfang, A. Nono, P. Kamgang, V. Ngako and M. F. Tchoua, "Cameroon Line Alkaline Magmatism (Central Africa): A Reappraisal,” The Geological Society of America Special paper, Vol. 478, 2011, pp. 173-189.

http://dx.doi.org/10.1130/2011.2478(09)

[2] B. Deruelle, I. Ngounouno and D. Demaiffe, "The 'Cameroon Hot Line’ (CHL): A Unique Example of Active Alkaline Intraplate Structure in Both Oceanic and Continental Lithospheres,” Comptes Rendus Geoscience, Vol. 339, No. 9, 2007, pp. 589-600. http://dx.doi.org/10.1016/j.crte.2007.07.007

[3] J. J. Fitton, "The Benue Trough and the Cameroon LineA Migrating Rift System in West Africa," Earth and Planetary Science Letters, Vol. 51, No. 1, 1980, pp. 132138. http://dx.doi.org/10.1016/0012-821X(80)90261-7

[4] D. C. Lee, A. N. Halliday, J. J. Fitton and G. Poli, "Isotopic Variations with Distance and Time in the Volcanic Islands of the Cameroon Line: Evidence for a Mantle Plume Origin,” Earth Planetary Science Letters, Vol. 123, No. 1-3, 1994, pp. 119-138 http://dx.doi.org/10.1016/0012-821X(80)90261-7 
[5] J. B. Meyers, B. R. Rosendahl, C. G. Harrison and Z. D. Ding, "Deep-Imaging Seismic and Gravity Results from the Offshore Cameroon Volcanic Line, and Speculation of African Hotlines,” Tectonophysics, Vol. 284, No. 1-2, 1998, pp. 31-63. http://dx.doi.org/10.1016/S0040-1951(97)00173-X

[6] T. Yokoyama, F. Aka, M. Kusakabe and E. Nakamura, "Plume-Lithosphere Interaction Beneath Mt. Cameroon Volcano, West Africa: Constraints From ${ }^{238} \mathrm{U}-{ }^{230} \mathrm{Th}^{2}{ }^{226} \mathrm{Ra}$ and Sr-Nd-Pb Isotopes Systematics," Geochimica et Cosmochimica Acta, Vol. 71, No. 7, 2007, pp. 1835-1854. http://dx.doi.org/10.1016/j.gca.2007.01.010

[7] C. E. Suh, R. S. Sparks, J. J. Fitton, S. N. Ayonghe, C. Annen and R. Nana, "The 1999 and 2000 Eruptions of Mount Cameroon: Eruption Behaviour and Petrochemistry of Lava," Bulletin of Volcanology, Vol. 65, No. 4, 2003, pp. 267-283. http://dx.doi.org/10.1007/s00445-002-0257-7

[8] M. Gountie Dedzo, A. Nedelec, T. Nono, T. Njanko, E. Font and P. Kamgang, "Magnetic Fabrics of the Miocene Ignimbrites from West-Cameroon: Implications for Pyroclastic Flow Source and Sedimentation," Journal of Volcanology and Geothermal Research, Vol. 203, No. 3, 2011, pp. 113-132.

[9] G. Bwele, “L’encyclopédie de la République unie du Cameroun,” Nouvelles Éditions Africaines, Abidjan, 1981.

[10] A. S. Neba, "Modern Geography of the Republic of Cameroon,” Neba Publishers, Camdem, 1987.

[11] P. Kamgang, E. Njonfang, A. Nono, M. Gountie Dedzo and M. F. Tchoua, "Petrogenesis of a Silicic Magma System: Geochemical Evidence from Bamenda Mountains, NW Cameroon, Cameroon Volcanic Line," Journal of African Earth Sciences, Vol. 58, No. 2, 2010, pp. 285-304. http://dx.doi.org/10.1016/j.jafrearsci.2010.03.008

[12] P. Kamgang, E. Njonfang, G. Chazot and F. Tchoua, "Géochimie et Géochronologie des Laves Felsiques des Monts Bamenda (Ligne Volcanique du Cameroun)," Comptes Rendus Géoscience, Vol. 339, No. 10, 2007, pp. 659-666. http://dx.doi.org/10.1016/j.crte.2007.07.011

[13] P. Kamgang, G. Chazot, E. Njonfang and F. Tchoua, "Geochemistry and Geochronology of Mafic Rocks from Bamenda Mountains (Cameroon): Source Composition and Crustal Contamination along the Cameroon Volcanic Line,” Comptes Rendus Geoscience, Vol. 340, No. 12, 2008, pp. 850-857. http://dx.doi.org/10.1016/j.crte.2008.08.008

[14] I. K. Njilah, H. N. Ajonina, K. V. Kamgang and M. Tchindjang, "K-Ar Ages, Mineralogy, Major and Trace Element Geochemistry of the Tertiary-Quaternary Lavas from the Ndu Volcanic Ridge N. W. Cameroon,” African Journal of Science and Technology (AJST), Vol. 5, No. 1, 2004, pp. 47 - 56.

[15] A. Marzoli, P. R. Renne, E. M. Piccirillo, F. Castorina, G. Bellieni and A. J. Melfi, "Silicic Magmas from the Continental Cameroon Volcanic Line (Oku, Bambouto and Ngaoundere): ${ }^{40} \mathrm{Ar} /{ }^{39} \mathrm{Ar}$ dates, petrology, Sr-Nd-O Isotopes and Their Petrogenetic Significance," Contributions to Mineralogy and Petrology, Vol. 135, No. 2-3, 1999, pp. 133-150.

\section{http://dx.doi.org/10.1007/s004100050502}

[16] R. Salminen, T. Tarvainen, A. Demetriades, M. Duris, F. Fordyce and V. Gregorauskiene, "FOREGS Geochemical Mapping Field Manual,” Geological Survey of Finland guide, Rovaniemi, 1998.

[17] D. L. Parkhurst and C. A. Appelo, "User's Guide to PHREEQC (Version 2)-A Computer Program for Speciation, Batch-Reaction, One-Dimensional Transport and Inverse Geochemical Calculations,” US Geological Survey Water-Resources Investigations, Report 99-4259, 1999, p. 310.

[18] A. Streckeisen, “To Each Plutonic Rock Its Proper Name,” Earth Science Reviews, Vol. 12, No. 1, 1976, pp. 1-33. http://dx.doi.org/10.1016/0012-8252(76)90052-0

[19] A. Streckeisen, "IUGS Subcommission on the Systematics of Igneous Rocks Classification and Nomenclature of Volcanic Rocks, Lamprophyres, Carbonatites and Melilitic Rocks. Recommendations and Suggestions,” Neues Jahrbuch für Mineralogie Stuttgart, Vol. 134, 1978, pp. $1-14$.

[20] A. Streckeisen, "Classification and Nomenclature of Volcanic Rocks, Lamprophyres, Carbonatites and Melilitic Rocks: Recommendations and Suggestions of the IUGS Sub Commission on the Systematics of Igneous Rocks: Geology," The Geological Society of America, Boulder, Vol. 7, No. 7, 1979, pp. 331-335.

[21] R. Schmid, "Descriptive Nomenclature and Classification of Pyroclastic Deposits and Frgments: Recommendations of the IUGS Subcommission on the Systematics of Igneous Rocks: Geology,” The Geological Society of America, Boulder, Vol. 9, No. 1, 1981, pp. 41-43.

[22] M. J. Le Bas and L. R. W. Maitre, A. Streckeisen and B. Zanettin, "A Chemical Classification of Volcanic Rocks Based on Total Alkali-Silica Diagram,” Journal of Petrology, Vol. 27, No. 3, 1986, pp. 745-750. http://dx.doi.org/10.1093/petrology/27.3.745

[23] Beeson, "Alkali Olivine Basalt, Sample KLPA-1, East Molokai Volcanoe Hawaii,” In: R. A. Loren, Ed., Petrolgy: The Study of Igneous, Sedimentary and Metamorphic Rocks, 2nd Edition, McGraw-Hill, New York, 2002, pp. 102-103.

[24] Coats, "Circle Creek Rhyolite, Sample 60NC145, Elko Country, Nevada,” In: R. A. Loren, Ed., Petrology: The Study of Igneous, Sedimentary and Metamorphic Rocks, 2nd Edition, McGraw-Hill, New York, pp. 126-127.

[25] W. Cross, J. P. Iddings, L. V. Pirsson and L. V. Washington, (1903): "Quantitative Classification of Igneous Rocks,” University of Chicago Press, Chicago, 1903.

[26] C. H. Kelsey, “Calculation of CIPW Norm,” Mineralogical Magazine, Vol. 34, 1965, pp. 276-282. http://dx.doi.org/10.1007/s004100050502

[27] E. P. Thornton and O. E. Tuttle, "Chemistry of Igneous Rocks-Differentiation Index,” American Journal of Science, Vol. 258, No. 9, 1960, pp. 664-684. http://dx.doi.org/10.2475/ajs.258.9.664

[28] H. A. Gorrell, "Classification of Formation Waters Based on Sodium Chloride Content," American Association of Petroleum Geologists Bulletin,” Vol. 42, No. 10, 1958, pp. 
2513.

[29] A. M. Piper, "A Graphic Procedure in the Geochemical Interpretation of Water Analyses," Transactions, American Geophysical Union, Vol. 25, No. 6, 1944, pp. 914923. http://dx.doi.org/10.1029/TR025i006p00914

[30] G. Z. Tanyileke, M. Kusakabe and W. C. Evans, "Chemical and Isotopic Characteristics of Fluids along the Cameroon Volcanic Line, Cameroon,” Journal of African Earth Science, Vol. 22, No. 4, 1996, pp. 433-44. http://dx.doi.org/10.1016/0899-5362(96)00025-5

[31] C. Dessert, B. Dupre, J. Gaillardet, M. Francois and C. Allegre, "Basalt Weathering Laws and the Impact of Basalt Weathering,” Chemical Geology, Vol. 202, No. 3-4, 2003, pp. 257- 273. http://dx.doi.org/10.1016/j.chemgeo.2002.10.001

[32] R. J. Gibbs, "Mechanisms Controlling World Water Chemistry,” Science, Vol. 17, No. 8, 1990, pp. 1088-1090.

[33] S. M. Yidana, B. Banoeng-Yakubo and P. A. Sakyi, "Identifying Key Processes in the Hydrochemistry of a Basin through the Combined Use of Factor and Regres- sion Models,” Journal of Earth System Science, Vol. 121, No. 2, 2012, pp. 491-507.

http://dx.doi.org/10.1007/s12040-012-0163-0

[34] A. L. Marechal, "Géologie et Giochimie des Sources Thermo-minérales du Cameroun,” Travaux et Documents de L'orstom N0 59, Orstom, Paris, 1976.

[35] N. S. Davis and J. R. De Wiest, "Hydrogeology,” Wiley \& Sons Inc., New York, 1966.

[36] H. Shinohara, W. Giggenbach, M. Kusakabe and T. Ohba, "Formation of Acid Volcanic Brines through Interaction of Magmatic Gases," Geochimica et Cosmochimica Acta, Vol. 67, No. 18, 2003, p. 433.

[37] E. J. Lynn, "Geographic Information Systems in WaterResources Engineering,” CRC Press (Taylor \& Francis Group), Boca Raton, 2009.

[38] A. Abdul-Rahman and M. Pilouk, "Spatial Data Modelling for 3D GIS,” Springer, New York, 2008.

[39] A. P. Gretchen, "GIS Cartography: A Guide to Effective Map Design,” CRC Press (Taylor \& Francis Group), Boca Raton, 2009. 